\title{
PENINJAUAN TINGKAT KESULITAN KEUANGAN MELALUI UKURAN PERUSAHAAN, PERTUMBUHAN PENJUALAN DAN LEVERAGE
}

\author{
Deden Edwar Yokeu Bernardin 1 \\ Universitas BSI Bandung \\ deden.eyb@gmail.com \\ Nadya Nurfaiziyah ${ }^{2}$ \\ Universitas BSI Bandung \\ nurfaiziyahnadya@gmail.com
}

\begin{abstract}
Abstrak - Kesulitan keuangan menjadi informasi yang sangat penting bagi perusahaan sebagai peringatan dini untuk mencegah terjadinya kebangkrutan atau likuidasi, hal tersebut dilihat dari ukuran perusahaan, pertumbuhan penjualan dan leverage di PT Pupuk Kujang. Penelitian ini bertujuan untuk mengukur dan mengetahui sejauh mana pengaruh yang diberikan oleh ukuran perusahaan, pertumbuhan penjualan dan leverage terhadap tingkat kesulitan keuangan. Penelitian ini menggunakan metode deskriptif dan verifikatif dengan pendekatan kuantitatif. Untuk mengkajinya digunakan Laporan Keuangan tahun 2008-2017 studi kasus di PT Pupuk Kujang. Hasil penelitian ini menunjukkan bahwa ukuran perusahaan dan pertumbuhan penjualan secara parsial berpengaruh tidak signifikan dengan arah negatif dalam memprediksi kesulitan keuangan sedangkan leverage secara parsial berpengaruh signifikan dengan arah positif dalam memprediksi kesulitan keuangan. Pengujian simultan dalam memprediksi kesulitan keuangan menunjukkan bahwa pengaruh yang diberikan oleh ukuran perusahaan, pertumbuhan penjualan serta leverage yaitu berpengaruh dengan signifikan. Dalam penelitian ini ditemukan hasil lain yakni adanya pengaruh yang paling kuat dan berarti dalam mempengaruhi kesulitan keuangan perusahaan oleh variabel leverage yang dilihat dengan penilaian debt to equity ratio. Dengan hasil penelitian ini, maka perusahaan dapat memanfaatkannya sebagai alat deteksi awal untuk mengantisipasi potensi terjadinya kesulitan keuangan.
\end{abstract}

Kata Kunci: Ukuran Perusahaan, Pertumbuhan Penjualan, Leverage, Kesulitan Keuangan

Abstract - Financial distress become very important information for companies as an early warning to prevent bankruptcy or liquidation, as seen from the size of the company, sales growth and leverage at PT Pupuk Kujang. This study aims to measure and determine the extent of the influence exerted by company size, sales growth and leverage on the level of financial distress. This research uses descriptive and verification methods with a quantitative approach. To study this, a 2008-2017 Financial Report was used in a case study at PT Pupuk Kujang. The results of this study indicate that company size and sales growth partially have insignificant effect with a negative direction in predicting financial distress while leverage partially has a significant effect with a positive direction in predicting financial distress. Simultaneous testing in predicting financial distress shows that the influence exerted by company size, sales 
growth and leverage is significantly influential. In this study, another result was found, namely the existence of the strongest and most significant influence in influencing the company's financial distress by the variable leverage seen by the debt to equity ratio assessment. With the results of this study, the company can use it as an early detection tool to anticipate potential financial distress.

Keywords: Firm size, Sales growth, Leverage, Financial distress

\section{PENDAHULUAN}

Kegiatan industri manufaktur pada masa sekarang ini persaingan yang sangat ketat didunia usaha yang sejenis ataupun tak sejenis (Mulyanti dan Priastari, 2016). Pertumbuhan dan persaingan antar perusahaan yang kompetitif diharapkan sejak dini mengantisipasi setiap perubahan yang terjadi dengan meningkatkan kinerja manajemen perusahaan yang selalu lebih baik dari sebelumnya (Rupaida dan Bernardin, 2016).

Meningkatkan kinerja perusahaan dapat dilakukan dengan menganalisa setiap laporan yang berhubungan dengan keuangan. Sumber informasi yang di inginkan oleh stake holder dan stock holder semuanya bersumber dari laporan keuangan yang di publish oleh perusahaan, dengan landasan tersebut keakuratan dalam keputusan sangat tinggi karena berdasarkan posisi, kinerja serta perubahan posisi keuangan perusahaan (Patunrui dan Yati, 2017). Hal ini dimaksudkan, untuk menanggulangi setiap kemungkinan perubahan kinerja perusahaan yang cenderung menurun yang kemudian dimungkinkan menyebabkan kepailitan. Peringatan dini sebelum terjadinya kepailitan biasanya ditandai dengan kondisi kesulitan keuangan (Nugraha dan Fajar, 2018).

Kesulitan keuangan adalah terjadinya penurunan kondisi keuangan suatu perusahaan yang terjadi sebelum perusahaan tersebut mengalami kebangkrutan atau likuidasi (Novietta dan Minan, 2017). Persaingan yang semakin ketat dalam industri pupuk nasional mewajibkan perusahaan untuk melakukan pengembangan sebagai antisipasi.

Industri pupuk dalam negeri mulai mengalami tekanan, hal ini disebabkan melemahnya harga jual seiring turunnya harga urea internasional (Sutrisno dan Zuraya, 2016). Harga urea pada tahun 2013 masih sebesar USD 363 per ton, namun di tahun 2018 melonjak drastis menjadi USD 224 per ton (IndexMundi, 2018). Selain itu, naiknya harga gas sebagai bahan baku utama pembuatan pupuk yang berada menjadi tantangan yang cukup berat bagi industri pupuk, tak terkecuali PT. Pupuk Kujang.

Di tengah fenomena yang terjadi, PT. Pupuk Kujang harus segera melakukan kajian (assesment) terhadap risiko yang dihadapi, hal ini dimaksudkan agar PT. Pupuk Kujang tidak mengalami penurunan keuntungan dan untuk mengantisipasi terjadinya risiko kepailitan. Dalam memprediksi tingkat kesulitan keuangan perusahaan, dapat digunakan berbagai macam pengukuran. Salah satunya dengan analisis rasio keuangan sebagai dasar pengukuran. Dalam penelitian ini model Zmijewski digunakan sebagai alat ukur tingkat kesulitan keuangan.

Model Zmijewski merupakan salah satu alat ukur dalam memprediksi yang ditemukan oleh Zmijewski pada tahun 1983 sudah menjadi hasil keilmuan selama 20 tahun terakhir yang kemudian 
ditelaah dan dikaji ulang (Prihanthini dan Sari, 2013). return on assets, debt to assets ratio dan current ratio merupakan alat analisa mengukur kinerja keuangan yang digunakan oleh Zmijewski. Memprediksi tingkat kesulitan keuangan selain menggunakan analisis ROA, DAR dan current ratio juga dapat dipengaruhi oleh faktor lainnya, dalam penelitian ini digunakan ukuran perusahaan, pertumbuhan penjualan dan leverage sebagai variabel lain yang dapat memprediksi kesulitan keuangan.

Ukuran perusahaan atau firm size dapat tercermin pada seberapa besar aset yang dimiliki oleh perusahaan tersebut (Ananto et al., 2017:96). Besarnya ukuran perusahaan, dapat mempengaruhi kemampuan perusahaan dalam mempertahankan usahanya, dan dapat terhindar dari kondisi financial distress (kesulitan keuangan). Namun, besarnya aset juga harus dapat meningkatkan penjualan bagi perusahaan.

Salah satu sumber pendapatan perusahaan adalah penjualan. Pertumbuhan penjualan merupakan kemampuan perusahaan untuk meningkatkan penjualan produk, baik dalam segi peningkatan kualitas produk atau peningkatan strategi pemasaran. Perusahaan dengan pertumbuhan penjualan positif dan tinggi akan cenderung dapat mempertahankan kontinuitas usahanya serta menurunkan potensi terjadinya kondisi kesulitan keuangan dibandingkan perusahaan dengan pertumbuhan penjualan yang negatif dan rendah (Rani et al., 2017). Perusahaan yang memiliki pertumbuhan penjualan rendah akan cenderung menggunakan utang sebagai sumber dana eksternal (Atiqoh dan Asyik, 2016).

$$
\text { Menurut Fahmi (2014:72) }
$$

perusahaan akan dikategorikan extreme leverage (utang ekstrim) apabila penggunaan utang yang terlalu tinggi dan perusahaan terjebak dalam tingkat utang yang tinggi dan sulit untuk melepaskan beban utang tersebut. Maka diperlukan analisis leverage, untuk mengukur seberapa besar modal yang dijadikan sebagai jaminan kepada kreditur. Kelebihan nilai utang tanpa diikuti dengan peningkatan modal yang dimiliki dimungkinkan adanya risiko perusahaan dalam kesulitan keuangan (Sari dan Putri, 2016).

Berdasarkan landasan fenomena tersebut, maka tujuan penelitian ini adalah untuk menganalisis besarnya pengaruh ukuran perusahaan, pertumbuhan penjualan dan leverage dalam memprediksi kesulitan keuangan baik secara parsial maupun simultan pada PT. Pupuk Kujang tahun 20082017.

\section{KAJIAN LITERATUR}

\section{Ukuran Perusahaan}

Ukuran perusahaan atau firm size mencerminkan seberapa besar aset yang dimiliki oleh perusahaan (Ananto et al., 2017). Menurut Susilawati et al (2017), jika suatu perusahaan memiliki aset yang semakin besar maka perusahaan tersebut dapat berinvestasi untuk aset lancar ataupun aset tetap dan juga dapat memenuhi permintaan produk. Selain itu, banyaknya aset yang dimiliki dan besarnya ukuran perusahaan dapat meyakinkan calon investor dalam menanamkan modalnya ke perusahaan tersebut, karena hal itu menunjukkan bahwa perusahaan dalam keadaan yang baik dalam jangka pendek maupun dalam jangka panjang (Nugraha, 2017).

Namun, jika perusahaan memiliki aset yang tidak terlalu besar, maka perusahaan tersebut diprediksi akan mengalami kesulitan apabila ingin melakukan pinjaman melalui bank atau lembaga keuangan lainnya (Fidyaningrum dan Retnani, 2017:7), 
karena umumnya bank atau lembaga keuangan lainnya menuntut pembayaran utang yang terlalu ketat. Semakin besar ukuran suatu perusahaan atau. Logaritma natural (Ln) digunakan sebagai alat untuk menstandarkan nilai pada saat proses perhitungan mengingat nilai aktiva perusahaan yang besar (Bernardin dan Pebryyanti, 2016). Untuk lebih detailnya maka dapat diformulasikan sebagai berikut:

Ukuran Perusahaan $=$ Ln $($ Total Assets $) \ldots$ (1)

Sumber: Susilawati et al (2017)

Dimana:

Ln = Logaritma natural

\section{Pertumbuhan Penjualan}

Menurut Harahap

(2013:309)

growth adalah persentase rasio pertumbuhan pos-pos perusahaan dari tahun ke tahun. Rasio pertumbuhan ini salah satunya dapat dilihat dari pertumbuhan penjualan.

Carvalho and Costa (2014) mendefinisikan sales growth: refers to the increased sales and services between the current and previous year in percentage. Sedangkan, menurut Widhiari dan Merkusiwati (2015) keberhasilan dalam operasional perusahaan dapat dicerminkan oleh pertumbuhan penjualan dari setiap waktu dengan membandingkan waktu yang telah berlalu dengan masa yang akan datang dalam proses dan pertumbuhan.

Perusahaan dengan pertumbuhan penjualan positif dan tinggi akan cenderung dapat mempertahankan kontinuitas usahanya serta menurunkan potensi terjadinya kondisi kesulitan keuangan dibandingkan perusahaan dengan pertumbuhan penjualan yang negatif dan rendah (Rani et al., 2017). Sedangkan, Rasio pertumbuhan penjualan yang rendah diprediksi akan mengakibatkan perusahaan mengalami kondisi kesulitan keuangan karena penjualan yang turun atau bahkan negatif akan berpengaruh terhadap aset, pendapatan, dan utang perusahaan.

Adapun rumus menghitung sales growth adalah sebagai berikut:

$$
\begin{aligned}
& \text { Sales Growth } \\
& =\frac{\text { Penjualan tahun ini }- \text { Penjualan tahun lalu }}{\text { Penjualan tahun lalu }}
\end{aligned}
$$

Sumber: Widhiari dan Merkusiwati (2015)

\section{Leverage}

Menurut Fahmi (2014:72) rasio leverage Menurut Fahmi (2014:72) rasio leverage sebagai alat untuk mengukur kemampuan perusahaan dalam proses usahanya yang dibiayai oleh hutang. Keutamaan dalam perhitungan atau mengukur dengan rasio leverage ini sangat penting guna pengukuran secara langsung oleh kreditur atas pemberian dana terhadap debitur sehingga risiko utangnya dapat dikaji terlebih dahulu (Srikalimah, 2017).

Perusahaan sebaiknya menyeimbangkan setiap keputusan utang yang disesuaikan dengan kemampuan perusahaan dalam membayar utang yang diajukan (Fahmi, 2014:72). Kelebihan nilai utang tanpa diikuti dengan peningkatan modal yang dimiliki dimungkinkan adanya risiko perusahaan dalam kesulitan keuangan (Sari dan Putri, 2016).

Dalam penelitian ini DER (debt to equity ratio) adalah Rasio leverage yang digunakan. Berikut perhitungan debt to equity ratio:

$$
\text { Debt to equity ratio }=\frac{\text { Total utang }(\text { Debt })}{\text { Ekititas }(\text { Equity })}
$$

Sumber: Kasmir (2017:158)

DER yang tinggi memungkinkan risiko dalam kesulitan keuangan bagi perusahaan, sehingga kecenderungan 
kerugian atas risiko keuangan perusahaan semakin tinggi.

\section{Kesulitan Keuangan}

Memasuki fase kesulitan keuangan dimungkinkan karena terjadi karena masalah keuangan yang di miliki perusahaan. Novietta dan Minan (2017) mengemukakan bahwa kesulitan keuangan yang dialami oleh perusahaan merupakan awal dari hilangnya suatu perusahaan dengan kata lain terjadinya bangkrut serta dilikuidasi.

Menurut Fahmi (2014:169) ketidakmampuan perusahaan dalam membayarkan semua kewajiban yang harus dibayar baik dalam jangka pendek ataupun jangka panjang adalah awal dari kesulitan keuangan.

Model Zmijewski merupakan salah satu alat ukur dalam memprediksi yang ditemukan oleh Zmijewski pada tahun 1983 sudah menjadi hasil keilmuan selama 20 tahun terakhir yang kemudian ditelaah dan dikaji ulang (Prihanthini dan Sari, 2013).

$X=-4,3-4,5 X_{1}+5.7 X_{2}-0,004 X_{3}$

Sumber: Novietta dan Minan (2017)

Dimana:

$\mathrm{X}_{1}=$ Return On Assets

$\mathrm{X}_{2}=$ Debt to Total Assets Ratio

$\mathrm{X}_{3}=$ Current Rasio

\section{Kualifikasi :}

$$
\begin{aligned}
& X=- \text { (negatif) : tidak berpotensi } \\
& X=+(\text { positif }): \text { berpotensi }
\end{aligned}
$$

Sumber: Sayari dan Mugan (2013)

It should be noticed that negative financial distress score indicates a relatively stronger financial health, whereas positive financial distress score refers to a relatively weaker financial health (Sayari and Mugan, 2013:98). Dengan kata lain, ketika skor kesulitan keuangan menunjukkan nilai negatif maka menunjukkan kesehatan perusahaan relatif kuat (tidak berpotensi mengalami kesulitan keuangan), ketika skor kesulitan keuangan menunjukkan nilai positif maka kesehatan keuangan perusahaan relatif lebih lemah (berpotensi mengalami kesulitan keuangan).

Berdasarkan uraian teori maka dapat disusun suatu paradigma penelitian berupa kerangka pemikiran sebagai berikut pada gambar 1

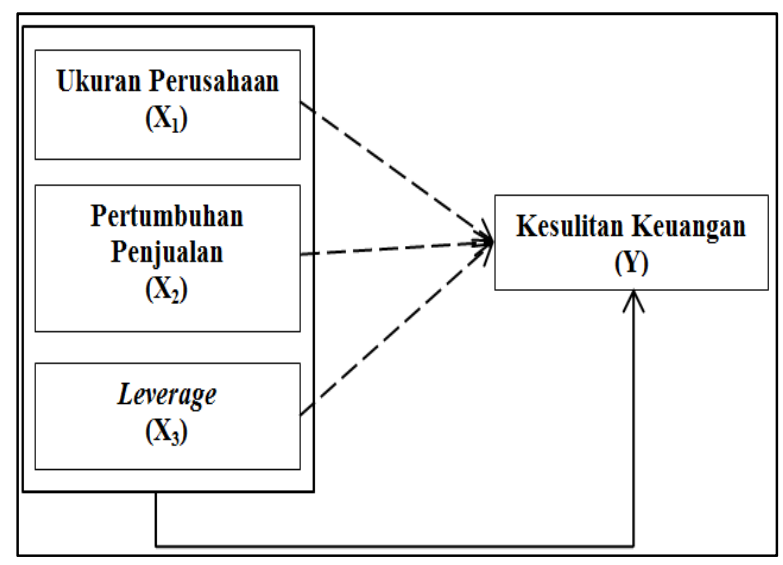

Gambar 1 Kerangka Pemikiran

\section{Hipotesis}

Hipotesis yang diajukan pada penelitian ini adalah sebagai berikut:

1. Ukuran perusahaan berpengaruh yang signifikan terhadap kesulitan keuangan.

2. Pertumbuhan penjualan berpengaruh yang signifikan terhadap kesulitan keuangan.

3. Leverage berpengaruh yang signifikan terhadap kesulitan keuangan.

4. Ukuran perusahaan, pertumbuhan penjualan dan leverage berpengaruh yang signifikan terhadap kesulitan keuangan.

\section{METODE PENELITIAN}

Dalam penelitian ini menggunakan tipe deskriptif dan verifikatif dengan pendekatan kuantitatif, dalam penelitian ini digunakan data sekunder berupa 
Laporan Keuangan PT. Pupuk Kujang tahun 2008-2017. Adapun teknik penelitian yang digunakan dalam penelitian ini adalah Analisis Regresi Berganda untuk mengukurnya harus dilakukan Uji Asumsi Klasik (Uji Normalitas Data, Uji Heteroskedastisitas, Uji Autokorelasi dan Uji Multikolinearitas). Serta diukur dan dihitung Koefisien Korelasi Koefisien Determinasi, sebagai landasan untuk pengujian hipotesis, Sugiyono (2013:159) Sugiyono (2014:277).

\section{HASIL DAN PEMBAHASAN}

\section{Deskriptif Data Hasil Variabel Penelitian}

Tabel 1. Ukuran Perusahaan, Pertumbuhan Penjualan, Leverage dan Kesulitan Keuangan PT. Pupuk Kujang Tahun 2008-2017

\begin{tabular}{|ccccc|}
\hline Tahun & $\begin{array}{c}\text { Ukuran } \\
\text { Perusahaan }\end{array}$ & $\begin{array}{c}\text { Pertumbuhan } \\
\text { Penjualan }\end{array}$ & Leverage & $\begin{array}{c}\text { Kesulitan } \\
\text { Keuangan }\end{array}$ \\
\hline 2008 & 29,08 & 0,25 & 4,23 & 0,60 \\
\hline 2009 & 29,05 & 0,02 & 2,23 & $-0,88$ \\
\hline 2010 & 28,96 & 0,17 & 1,99 & $-0,66$ \\
\hline 2011 & 29,04 & 0,09 & 1,68 & $-1,07$ \\
\hline 2012 & 29,10 & 0,24 & 1,27 & $-1,73$ \\
\hline 2013 & 29,17 & $-0,03$ & 1,18 & $-1,67$ \\
\hline 2014 & 29,20 & 0,07 & 1,16 & $-1,57$ \\
\hline 2015 & 29,35 & 0,04 & 1,58 & $-0,89$ \\
\hline 2016 & 30,01 & 0,11 & 0,47 & $-2,51$ \\
\hline 2017 & 30,00 & 0,08 & 0,45 & $-2,60$ \\
\hline
\end{tabular}

Sumber: data diolah

Berdasarkan tabel 1, terlihat bahwa ukuran perusahaan berada dalam keadaan yang cukup stabil. Disamping itu, pertumbuhan penjualan berada dalam kondisi yang fluktuatif. Leverage kondisinya cukup baik karena setiap tahunnya secara angka relative menurun akan tetapi leverage berada diatas standar rasio. Kondisi kesulitan keuangan dalam table 1 terlihat bahwa nilai kesulitan keuangan PT. Pupuk Kujang di dibawah cut-off, dimana nilai $\mathrm{X}$ yang dimiliki oleh perusahaan lebih kecil dari 0 , kecuali kondisi pada tahun 2008.

\section{Uji Asumsi Klasik}

Untuk mengkaji dan mengukur pengujian hipotesis terlebih dahulu dilakukan uji asumsi klasik yaitu: uji normalitas, uji heteroskedastisitas, uji autokorelasi dan uji multikolinearitas.

\section{Uji Normalitas Data}

Tabel 2. Hasil Uji Asumsi Normalitas One-Sample Kolmogorov-Smirnov Test

\begin{tabular}{|c|c|c|c|c|c|}
\hline \multicolumn{6}{|c|}{ One-Satinple Kolinogorov-Sintinorv Test } \\
\hline & & $\begin{array}{c}\text { Ukuran } \\
\text { Perusahaan }\end{array}$ & $\begin{array}{l}\text { Pertumbuhan } \\
\text { Penjualan }\end{array}$ & Leverage & $\begin{array}{l}\text { Kesulitan } \\
\text { Keuangan }\end{array}$ \\
\hline \multicolumn{2}{|l|}{$\mathrm{N}$} & 10 & 10 & 10 & 10 \\
\hline \multirow{2}{*}{$\begin{array}{l}\text { Normal } \\
\text { Parameters }{ }^{\mathrm{a}, \mathrm{b}}\end{array}$} & Mean & 29,2958 & 1049 & 1,6240 & $-1,2981$ \\
\hline & $\begin{array}{l}\text { Std. } \\
\text { Deviation }\end{array}$ & ,38871 & 09053 & 1,08180 & 94031 \\
\hline \multirow{3}{*}{$\begin{array}{l}\text { Most Extreme } \\
\text { Differences }\end{array}$} & Absolute & 298 &, 173 &, 187 &, 148 \\
\hline & Positive & ,298 &, 173 & 187 & ,148 \\
\hline & Negative &,- 193 &,- 129 &,- 139 &,- 124 \\
\hline \multicolumn{2}{|c|}{ Kolmogorov-Smirnov Z } & 943 &, 548 &, 592 & ,469 \\
\hline \multicolumn{2}{|c|}{ Asymp. Sig. (2-tailed) } &, 336 & ,925 &, 874 & ,980 \\
\hline \multicolumn{2}{|c|}{$\begin{array}{l}\text { a. Test distributionis } \\
\text { Normal. }\end{array}$} & & & & \\
\hline \multicolumn{2}{|c|}{ b. Calculated from data. } & & & & \\
\hline
\end{tabular}

Sumber: Hasil olah SPSS 20

Berdasarkan tabel 2, nilai Asymp Sig (2-tailed) menunjukkan nilai lebih besar dari batas yakni lebih besar dari 0,05 , maka dapat disimpulkan bahwa data yang dimiliki dalam penelitian ini terdistribusi normal sehingga layak untuk dilanjutkan kajiannya atau penelitiannya.

Uji Heteroskedastisitas

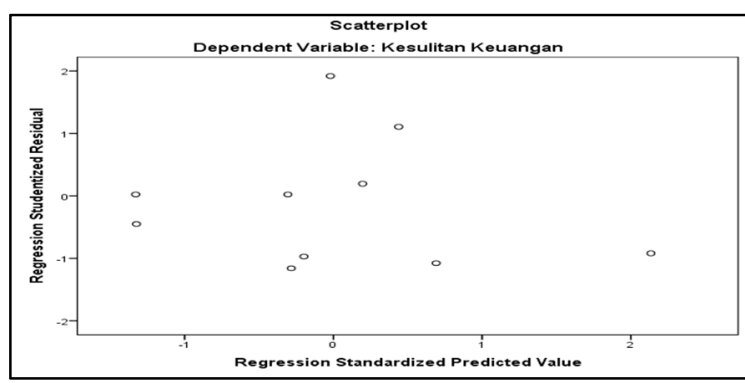

Gambar 2. Hasil Pengujian Heteroskedastisitas Sumber: Hasil olah SPSS 20 
Berdasarkan hasil pada gambar 2, menunjukkan hasil bahwa titik-titik yang terdapat pada uji ini terlihat menyebar dan tidak membentuk suatu pola apapun, maka dengan demikian data pada penelitian ini tidak terjadi kondisi heteroskedastisitas sehingga layak diteruskan penelitiannya.

\section{Uji Autokorelasi}

Tabel 3 Hasil Uji Asumsi Autokorelasi

\begin{tabular}{cc}
\multicolumn{2}{c}{ Run Test } \\
\hline & $\begin{array}{c}\text { Unstandardized } \\
\text { Residual }\end{array}$ \\
\hline Test Value $^{\mathrm{a}}$ &,- 03082 \\
\hline Cases $<$ Test Value $^{2}$ & 5 \\
\hline Cases > $=$ Test Value $^{2}$ & 5 \\
\hline Total Cases & 10 \\
\hline Number of Runs & 5 \\
\hline Z &,- 335 \\
\hline Asymp. Sig. (2-tailed) &, 737
\end{tabular}

Sumber: Hasil olah SPSS 20

Berdasarkan tabel 3, hasil uji autokorelasi terlihat bahwa nilai Asymp Sig. (2-Tailed) menunjukkan nilai lebih besar dari batas yang diukur yakni sig 5\% atau 0,05, maka dengan hasil tersebut dapat dikatakan bahwa data penelitian tidak terjadi autokorelasi.

\section{Uji Multikolinearitas}

Tabel 4 Hasil Pengujian Asumsi Multikolinearitas

\begin{tabular}{|c|c|c|}
\hline \multicolumn{3}{|c|}{ Coefficients } \\
\hline \multirow{2}{*}{ Model } & \multicolumn{2}{|c|}{ Collinearity Statistics } \\
\hline & Tolerance & VIF \\
\hline \multicolumn{3}{|l|}{ (Constant) } \\
\hline $\begin{array}{l}\text { Ukuran } \\
\text { Perusahaan }\end{array}$ & ,603 & 1,657 \\
\hline $\begin{array}{c}\text { Pertumbuhan } \\
\text { Penjualan }\end{array}$ & ,766 & 1,306 \\
\hline Leverage & ,489 & 2,045 \\
\hline $\begin{array}{l}\text { endent Vari } \\
\text { ulitan.Keuar }\end{array}$ & & \\
\hline
\end{tabular}

Sumber: Hasil olah SPSS 20
Berdasarkan tabel 4, nilai tolerance ukuran perusahaan 0,603 , pertumbuhan penjualan 0,766 dan leverage 0,489. Dengan hasil tersebut menunjukkan bahwa masing-masing nilai tolerance tidak lebih dari 0,1 dan nilai Variance Inflation Factor (VIF) juga menunjukkan lebih kecil dari 10, maka dapat diartikan bahwa data tidak terjadi multikolinieritas.

\section{Koefisien Determinasi}

Tabel 6 Hasil Pengujian Koefisien Determinasi

\begin{tabular}{|c|c|c|c|c|}
\hline \multicolumn{5}{|c|}{ Model Summary } \\
\hline \multirow[t]{3}{*}{ Model } & $\mathrm{R}$ & R Square & Adjusted R Square & Std. Error of the \\
\hline & & & & Estimate \\
\hline &, $977^{\mathrm{a}}$ &, 954 &, 932 &, 24608 \\
\hline \multicolumn{5}{|c|}{ a. Predictors: (Constant), Leverage, Pertumbuhan Penjualan, Ukuran } \\
\hline \multicolumn{5}{|c|}{ Perusahaan } \\
\hline
\end{tabular}

Sumber: Hasil olah SPSS 20

Berdasarkan hasil yang disajikan pada tabel 6, maka diperoleh nilai pengaruh senilai 0,954 , ini mengartikan bahwa ukuran perusahaan, pertumbuhan penjualan dan leverage bersama-sama mempengaruhi kesulitan keuangan sebesar $95,4 \%$ serta nilai pengaruh yang tak diperhitungkan adalah sebesar $4,6 \%$.

\section{Hasil Analisis Regresi Linier Berganda}

Tabel 7 Analisis Regresi Linier Berganda

\begin{tabular}{|c|c|c|c|c|c|}
\hline \multicolumn{6}{|c|}{ Coefficients } \\
\hline \multirow{3}{*}{ Model } & \multirow{2}{*}{\multicolumn{2}{|c|}{$\begin{array}{c}\text { Unstandardized } \\
\text { Coefficients }\end{array}$}} & \multirow{3}{*}{$\begin{array}{l}\begin{array}{c}\text { Standardized } \\
\text { Coefficients }\end{array} \\
\text { Beta }\end{array}$} & \multirow{3}{*}{$\mathrm{t}$} & \multirow{3}{*}{ Sig. } \\
\hline & & & & & \\
\hline & B & Std. Error & & & \\
\hline (Constant) & 12,083 & 8,049 & & 1,501 & ,184 \\
\hline $\begin{array}{l}\text { Ukuran } \\
\text { perusahaan }\end{array}$ &,- 496 & ,272 &,- 205 & $-1,826$ &, 118 \\
\hline $\begin{array}{l}\text { Pertumbuhan } \\
\text { penjualan }\end{array}$ &,- 667 & 1,035 &,- 064 &,- 644 &, 543 \\
\hline Leverage & ,751 & , 108 & ,864 & 6,922 &, 000 \\
\hline
\end{tabular}

a. Dependent Variabel: Kesulitan keuangan 
Sumber: Hasil olah SPSS 20

Persamaan regresi linier bergandanya adalah sebagai berikut:

$$
\begin{array}{r}
Y=12,083+\left(-0,496 X_{1}\right)+(- \\
\\
\left.0,667 X_{2}\right)+0,751 X_{3}+e
\end{array}
$$

\section{Uji Simultan}

Tabel 8. Hasil Uji Simultan (Uji F) ANOVAa

\begin{tabular}{lrrrrr}
\hline Model & $\begin{array}{l}\text { Sum of } \\
\text { Squares }\end{array}$ & df & Mean Square & \multicolumn{1}{l}{ F } & Sig. \\
\hline Regression & 7,594 & 3 & 2,531 & 41,803 &, $000^{b}$ \\
\hline Residual &, 363 & 6 &, 061 & & \\
\hline Total & 7,958 & 9 & & & \\
\hline
\end{tabular}

a. Dependent Variable: Kesulitan keuangan

b. Predictors: (Constant), Leverage, Pertumbuhan penjualan, Ukuran pertusahaan

Sumber: Hasil olah SPSS 20

\section{Pengaruh Ukuran Perusahaan terhadap Kesulitan Keuangan}

Hasil penelitian ini menunjukkan data yang diperoleh dalam mengukur pengaruh ukuran perusahaan dalam memprediksi kondisi kesulitan keuangan adalah thitung lebih kecil dari tabel $(-1,826<$ 2,446 ) dengan tingkat signifikan $0,118>$ 0,05 dan nilai standardized coefficients beta diperoleh dengan nilai -0,205 atau sama dengan $-20,5 \%$ besarnya pengaruh yang diberikan ukuran perusahaan terhadap kesulitan keuangan. Berdasarkan perhitungan dan pengkajian hasil tersebut maka $\mathrm{H}_{0}$ diterima dan $\mathrm{Ha}$ ditolak. Ini menunjukkan terdapat pengaruh yang tidak signifikan dengan arah negatif antara ukuran perusahaan dalam memprediksi kesulitan keuangan.

\section{Pengaruh Pertumbuhan Penjualan terhadap Kesulitan Keuangan}

Hasil penelitian ini menunjukkan data yang diperoleh dalam mengukur pengaruh pertumbuhan penjualan dalam memprediksi kondisi kesulitan keuangan adalah thitung lebih kecil dari tabel $(-0,644<$ $2,446)$ dengan tingkat signifikan 0,543 dan nilai standardized coefficients beta diperoleh nilai sebesar -0,640 atau sama dengan $-64 \%$ adalah besarnya pengaruh diberikan oleh pertumbuhan penjualan terhadap kesulitan keuangan perusahaan. Berdasarkan perhitungan dan pengkajian tersebut maka $\mathrm{H}_{0}$ diterima dan $\mathrm{Ha}$ ditolak. Ini menunjukkan bahwa terdapat berpengaruh yang signifikan dengan arah negatif antara pertumbuhan penjualan dalam memprediksi kesulitan keuangan.

\section{Pengaruh Leverage terhadap Kesulitan Keuangan}

Hasil penelitian ini menunjukkan data yang diperoleh dalam mengukur pengaruh leverage yang diproksikan dengan (DER) debt to equity ratio dalam memprediksi kesulitan keuangan adalah thitung lebih kecil dari tabel $(6,922>2,446)$ dengan tingkat signifikan 0,000 dan nilai standardized coefficients beta diperoleh nilai sebesar 0,864 atau sama dengan $86,4 \%$ adalah besarnya pengaruh yang diberikan leverage terhadap kesulitan keuangan pada perusahaan. Berdasarkan hasil tersebut maka $\mathrm{H}_{0}$ ditolak dan Ha diterima. Ini menunjukkan bahwa terdapat pengaruh signifikan yang diberikan dengan berbanding lurus antara leverage dalam memprediksi kondisi kesulitan keuangan dari perusahaan.

\section{Pengaruh Ukuran Perusahaan, Pertumbuhan Penjualan dan Leverage terhadap Kesulitan Keuangan}




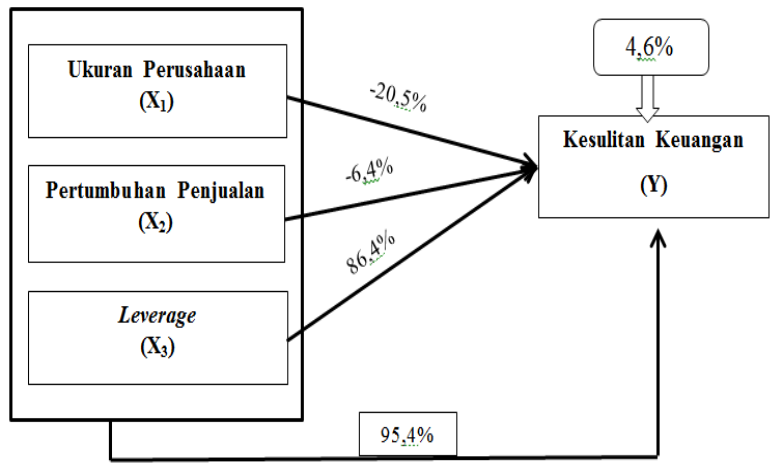

Gambar 2 Pengaruh Ukuran Perusahaan, Pertumbuhan Penjualan dan Leverage dalam Memprediksi Kesulitan Keuangan

Berdasarkan tabel 6, diperoleh nilai $\mathrm{R}$ Square senilai 0,954 atau sama dengan 95,4\%. Serta nilai pengaruh dari faktor lainnya yang tidak diteliti adalah sebesar $4,6 \%$. Sedangkan pada tabel 8, menunjukkan $F_{\text {hitung sebesar } 41,803}$ dengan nilai signifikan sebesar 0,000 . Diperoleh $F_{\text {tabel }}$ sebesar 4,76, maka $F_{\text {hitung }}$ lebih besar dari $F_{\text {tabel }}(41,803>4,76)$ dan nilai signifikan sebesar $0,000<0,05$. Berdasarkan hasil tersebut, maka $\mathrm{H}_{0}$ ditolak dan Ha diterima. Ini menunjukkan bahwa secara simultan terdapat pengaruh yang signifikan antara ukuran perusahaan, pertumbuhan penjualan dan leverage dalam memprediksi kesulitan keuangan.

Hasil tersebut menunjukkan bahwa untuk memprediksi kesulitan keuangan, maka ukuran perusahaan, pertumbuhan penjualan dan leverage harus berjalan bersama. Karena dengan besarnya ukuran perusahaan, meningkatnya pertumbuhan penjualan dan menurunnya leverage akan menunjang kinerja keuangan yang nantinya akan didistribusikan ke aset untuk meningkatkan penjualan, dengan harapan laba yang dihasilkan semakin besar, sehingga perusahaan dapat memenuhi kewajibannya. Dengan demikian, akan memperkecil potensi kesulitan keuangan.

Temuan penelitian ini adalah dari ketiga variabel independen yang diteliti yaitu ukuran perusahaan, pertumbuhan penjualan dan leverage, variabel yang memiliki pengaruh paling kuat dan positif terhadap kesulitan keuangan adalah variabel leverage. Variabel leverage yang diwakilkan dengan menggunakan debt to equity ratio memiliki pengaruh sebesar $86,4 \%$. Hal ini mengartikan, ketika leverage mengalami peningkatan maka potensi terjadinya tingkat kesulitan keuangan pun akan semakin besar, begitu pula sebaliknya.

\section{PENUTUP}

Tujuan penelitian ini adalah untuk mengkaji pengaruh yang diberikan antar variabel yaitu variabel ukuran perusahaan, pertumbuhan penjualan, leverage dan kesulitan keuangan di PT Pupuk Kujang. Hasil penelitian ini didapat pengaruh yang tidak signifikan dengan arah pengaruh negatif antara ukuran perusahaan dalam memprediksi kondisi kesulitan keuangan perusahaan, terdapat pengaruh yang diberikan tidak signifikan dengan arah negatif oleh pertumbuhan penjualan terhadap prediksi kesulitan keuangan dari perusahaan dan terdapat kondisi pengaruh yang diberikan oleh leverage secara signifikan dengan arah positif dalam memprediksi kesulitan keuangan. Serta secara simultan, terdapat pengaruh yang signifikan antara ukuran perusahaan, pertumbuhan penjualan dan leverage dalam memprediksi kesulitan keuangan.

Hasil lain yang ditemukan pada penelitian ini adalah terdapat pengaruh yang paling kuat dalam memprediksi kesulitan keuangan perusahaan yaitu variabel leverage, yang dilihat dengan menggunakan penilaian debt to equity ratio di PT Pupuk Kujang. Dengan hasil tersebut, maka perusahaan dapat memanfaatkannya sebagai sinyal untuk mengantisipasi potensi terjadinya kesulitan keuangan. 
Saran yang peneliti coba berikan bagi PT Pupuk Kujang yaitu diharapkan dapat menjalankan manajemen perusahaan ke arah yang lebih baik, salah satunya dengan cara mengelola aset secara lebih efisien dan efektif untuk meningkatkan penjualan dan menghasilkan laba yang lebih besar agar dapat memenuhi kewajibannya dan menjaga profitabilitas perusahaan. Sehingga dapat menarik minat para investor dan kreditor.

\section{DAFTAR PUSTAKA}

Ananto, R. P., Mustika, R., dan Handayani, D. (2017). Pengaruh Good Corporate Governance (GCG), Leverage, Profitabilitas dan Ukuran Perusahaan Terhadap Financial Distress Pada Perusahaan Barang Konsumsi Yang Terdaftar Di Bursa Efek Indonesia. Jurnal Ekonomi \& Bisnis Dharma Andalas, 19(1), 1939. ISSN 2527 - 3469

Atiqoh, Z., \& Asyik, N. F. (2016). Pengaruh Kinerja Keuangan, Size, Pertumbuhan Penjualan, Dan Kepemilikan Saham Terhadap Struktur Modal. Jurnal IImu Dan Riset Akuntansi, 5(5), 1-18. ISSN : 2460-0585

Bernardin, D. E. Y., dan Pebryyanti, D. I. (2016). Nilai Harga Saham yang Dipengaruhi oleh Laba Bersih dan Ukuran Perusahaan. Ecodemica, IV(1), 74-85. ISSN: 2355-0295

Carvalho, L., dan Costa, T. (2014). Small and Medium Enterprises (SMEs) and Competitiveness: An Empirical Study, 2(2), 88-95. ISSN 23282185

Fahmi, I. (2014). Pengantar Manajemen Keuangan. Bandung: Penerbit
Alfabeta.

Fidyaningrum, A., \& Retnani, E. D. (2017). Pengaruh GCG dan Firm Size Terhadap Perusahaan yang Mengalami Financial Distress. Jurnal IImu Dan Riset Akuntansi, 6. ISSN : 2460-0585 Vol.6 No.6

Harahap, S. S. (2013). Analisis Kritis Atas Laporan Keuangan. Jakarta: Penerbit Rajawali Pers.

IndexMundi. (2018). Urea Monthly Price US Dollars per Metric Ton. Retrieved from https://www.indexmundi.com/com modities/?commodity=urea\&mont hs $=60$

Kasmir. (2017). Analisis Laporan Keuangan. Jakarta: PT. RajaGrafindo Persada.

Mulyanti, D., \& Priastari, R. (2016). Pengaruh Struktur Aktiva dan Pertumbuhan Penjualan Terhadap Penentuan Struktur Modal, 35-40.

Mulyanti, D., dan Supriyani, R. L. (2018). Pengaruh Perputaran Kas dan Perputaran Persediaan Terhadap Likuiditas pada PT Ultra Jaya, Tbk., 18(1), 34-42. ISSN: 2597$792 X$

Novietta, L., dan Minan, K. (2017). Komparasi Model Kebangkrutan Pada Perusahaan Tekstil dan Garmen yang Terdaftar di Bursa Efek Indonesia. Jurnal Akuntansi dan Bisnis, 3(1), 118-143. ISSN: 2503-0337

Nugraha, A., \& Fajar, C. M. (2018). Financial Distress pada PT Panasia Indo Resources Tbk. Jurnal Inspirasi Bisnis Dan Manajemen, 2(1), 29-42.

Nugraha, M. K. (2017). Pengaruh Kinerja Keuangan, Ukuran Perusahaan dan Keputusan Investasi Terhadap Nilai Perusahaan. Jurnal IImu Dan 
Riset Akuntansi, 6(1), 312-328. ISSN : 2460-0585

Patunrui, K. I. A., \& Yati, S. (2017). Analisis Penilaian Financial Distress Menggunakan Model Altman ( Z- Score ) Pada Perusahaan Farmasi Yang Terdaftar di Bursa Efek Indonesia Periode 2013-2015, 5(1), 55-71.

Prihanthini, N. M. E. D., dan Sari, M. M. R. (2013). Analisis Prediksi Kebangkrutan Dengan Model Grover, Altman Z-Score, Springate Dan Zmijewski Pada Perusahaan Food And Beverage di BEI, 3, 544560. ISSN: 2302-8556

Rani, D. R., Hardi, dan Azhar, A. (2017). Pengaruh Likuiditas, Leverage, Profitabilitas, Agency Cost Dan Sales Growth Terhadap Kemungkinan Terjadinya Financial Distress (Studi Empiris Pada Perusahaan Manufaktur yang Terdaftar di BEI. JOM FEKON, 4(1), 3661-3675.

Rismawanti, R., Sukarmanto, E., dan Nurhayati. (2017). Pengaruh Likuiditas, Sales Growth dan Leverage dalam Memprediksi Kondisi Financial Distress, 3(1), 17. ISSN: 2302-8556

Rupaida, S. A., dan Bernardin, D. E. Y. (2016). Pengaruh Biaya Produksi Dan Biaya Promosi Terhadap Penjualan PT. Ultrajaya Milk Industry Tbk. Ekspansi, 8(2), 261275.

Sari, N. L. K. M., dan Putri, I. G. A. M. A. D. (2016). Kemampuan Profitabilitas Memoderasi Pengaruh Likuiditas dan Leverage Terhadap Financial Distress. EJurnal Ekonomi Dan Bisnis Universitas Udayana, 10(5), ISSN: 3419-3448.
Sayari, N., dan Mugan, F. N. C. S. (2013). Cash Flow Statement as an Evidence for Financial Distress, 1(3), 95-103. DOI: 10.13189/ujaf.2013.010302

Simanjuntak, C., Titik, F., dan Aminah, W. (2017). Pengaruh Rasio Keuangan Terhadap Financial Distress (Studi Pada Perusahaan Transportasi yang Terdaftar di Bursa Efek Indonesia Periode 2011- 2015), $4(2)$, 1580-1587. ISSN : 23559357

Srikalimah. (2017). Pengaruh Profitabilitas, Likuiditas dan Leverage Dalam Memprediksi Financial Distress (Studi Empiris Pada Perusahaan Manufaktur yang Terdaftar di BEI Periode 2009-2013), 2(1), 43-66. ISSN: 2541-0180

Susilawati, D., Sofianty, D., \& Sukarmanto, E. (2017). Pengaruh Profitabilitas, Ukuran Perusahaan dan Leverage Terhadap Financial Distress Pada Perusahaan yang Terdaftar di Bursa Efek Indonesia ( BEI ) ( Studi Empiris Pada Perusahaan Sub Sektor Minyak dan Gas Bumi Periode Tahun 2010-2015 ). Prosiding Akuntansi, (2460-6561), 208-214. ISSN: 2541-0180

Sutrisno, D., dan Zuraya, N. (2016). Industri Pupuk Nasional Terancam. Jakarta: Republika.co.id. Retrieved from https://www.republika.co.id/berita/ ekonomi/makro/16/09/13/odfj9438 3-industri-pupuk-nasionalterancam

Widhiari, N. L. M. A., dan Merkusiwati, N. K. L. A. (2015). Pengaruh Rasio Likuiditas, Leverage, Operating Capacity, dan Sales Growth Terhadap Financial Distress, 2, 
456-469. ISSN: 2302-8556

Wulandari, F., Burhanudin, dan Widayanti, R. (2017). Analisis Prediksi Kebangkrutan Menggunakan Metode Altman (ZScore) Pada Perusahaan Farmasi (Studi Kasus Pada Perusahaan Yang Terdaftar di Bursa Efek Indonesia Tahun 2011-2015), 2, 15-27. ISSN: 1410-4571 